\title{
Molecular and taxonomic characterisation of introduced specimens of Poecilia reticulata in the lower Paraguay River basin (Cyprinodontiformes: Poeciliidae)
}

\author{
Juan José Rosso ${ }^{1,2,3}$, Franco del Rosso ${ }^{3,4}$, Ezequiel Mabragaña ${ }^{1,2,3}$, Nahuel F. Schenone ${ }^{5}$, \\ Esteban Avigliano ${ }^{2,3,6}$ and Juan Martín Díaz de Astarloa ${ }^{1,2}$
}

Poeciliids comprise around 300 species inhabiting the fresh and brackish waters of the Americas and Africa. Poecilia reticulata is native to Northeastern South America and Trinidad and Tobago. In this paper, introduced specimens of $P$. reticulata collected in the lower Paraguay River in Argentina, were characterized by means of molecular and taxonomic approaches. We further explore, by means of DNA Barcoding, the singularity of the genetic identity of these specimens. Ocurrence of $P$. reticulata in the lower Paraguay River represents the first record of this species in Argentina. Thirteen individuals of $P$. reticulata were collected. DNA barcoding showed that all five specimens sampled belong to a single mitochondrial lineage, which was also present in 11 countries from five continents. The distance-based tree clearly grouped separetely four different clusters of $P$. reticulata when including public data. Genetic distance between the most divergent $P$. reticulata almost paralleled distance between this species and Poecilia mexicana and P. vivipara. Established populations from Paraguay could be one of the plausible sources for the introduced populations recorded in the lower Paraguay River. The presence of $P$. reticulata in an open waterway with known drainage to a natural stream is of major concern.

Keywords: Argentina, DNA Barcoding, Guppy, Poecilia, Taxonomy.

Poecilídeos compreendem cerca de 300 espécies que habitam águas doces e salobras das Américas e África. Poecilia reticulata é nativa do nordeste da América do Sul e Trinidad e Tobago. Neste trabalho, espécimes introduzidos de $P$. reticulata coletados no baixo rio Paraguai na Argentina, foram caracterizados por meio de abordagens moleculares e taxonômicas. Exploramos ainda, por meio de DNA Barcoding, a singularidade da identidade genética destes espécimes. A ocorrência de $P$. reticulata no baixo rio Paraguai representa o primeiro registro dessa especie na Argentina. Treze indivíduos de $P$. reticulata foram coletados. O Barcoding mostrou que todos os espécimes pertencem a uma única linhagem mitocondrial, a qual está presente em 11 países dos cinco continentes. A árvore de distâncias agrupou separadamente quatro clusters diferentes de $P$. reticulata quando incluindo dados públicos. A distância genética entre os agrupamentos mais divergentes de $P$. reticulata quase igualou a distância entre esta espécie e Poecilia mexicana e $P$. vivipara. As populações estabelecidas no Paraguai poderiam ser uma das fontes plausíveis para as populações introduzidas registradas no baixo rio Paraguai. A presença de $P$. reticulata em um canal aberto com drenagem conhecida para um córrego natural é de grande preocupação.

Palavras-chave: Argentina, DNA Barcoding, Guppy, Poecilia, Taxonomia.

\footnotetext{
${ }^{1}$ Grupo de Biotaxonomía Morfológica y Molecular de Peces, Instituto de Investigaciones Marinas y Costeras (IIMyC-CONICET), Universidad Nacional de Mar del Plata, Funes 3350, 7600 Mar del Plata, Buenos Aires, Argentina. (JJR) plurosso@yahoo.com.ar (corresponding author), (EM) emabraga@mdp.edu.ar, (JMDA) astarloa@mdp.edu.ar

${ }^{2}$ Consejo Nacional de Investigaciones Científicas y Técnicas (CONICET), Godoy Cruz 2290, C1425FQB Buenos Aires, Argentina.

${ }^{3}$ Fundación Bosques Nativos Argentinos para la Biodiversidad, Colombres 962 Piso 3A, C1218ABL Buenos Aires, Argentina.

${ }^{4}$ Ministerio de la Producción y Ambiente de la Provincia de Formosa, Belgrano 878, $6{ }^{\text {th }}$ floor, 3600 Formosa, Argentina. fradelrosso@ hotmail.com

${ }^{5}$ Centro de Investigaciones Antonia Ramos (CIAR), Acceso Balneario Bonito s/n, 3361 Villa Bonita, Campo Ramón, Departamento de Oberá, Misiones, Argentina. nahuelschenone@hotmail.com

${ }^{6}$ Instituto de Investigaciones en Producción Animal (INPA-CONICET), Facultad de Ciencias Veterinarias, Universidad de Buenos Aires, Av. Chorroarín 280, C1427CWO Buenos Aires, Argentina. crotalus1451@yahoo.com.ar
} 


\section{Introduction}

Poeciliids are small ovoviviparous fish that thrive in small, often ephemeral, freshwater environments. Their high reproduction rate is the biological key to thrive quickly in these ephemeral aquatic environments with just a small temporal window of favorable environmental conditions (Meffe, Snelson, 1989). Due to their high capacity to reproduce in captivity, poeciliids have become one of the most widespread species in the aquarium trade and are also commonly used for experimental studies in biology (Magurran, 2005).

The guppy, Poecilia reticulata Peters, 1859, is native of Northeastern South America and Trinidad and Tobago, with the type locality in the Guayre River in Venezuela. Native range of this species includes Brazil, Guyana, Venezuela, and Trinidad and Tobago (Rosen, Bayley, 1963). Currently, its presence in natural environments is known to occur in more than 69 countries outside of the species native range (Deacon et al., 2011). Known introduced range includes Asia, Australasia-Pacific, Europe, North America, and South America (GBIF, 2016). In South America, poecillids have been recorded mostly in the northern region of the continent. Just recently, by means of voucher examination from several Museums worldwide, the presence of this invasive species was confirmed in Paraguay (Lucinda, 2017).

Multiple introductions of guppies worldwide are likely to have occurred for mosquito control and release from domestic aquariums. There are official records of its introduction for mosquito control in Australia (Vipan, 1910) and in California swamps of United States (Shapovalov et al., 1981; Dill, Cordone, 1997). In Australia, wild populations were established before the 1970s (Allen et al., 2002). In the United States, $P$. reticulata is considered a hazard to native cyprinids and killifishes and has been implicated in the decline of native fishes in the southwest (Courtenay, Stauffer, 1990). It is also a known carrier of trematode parasites, which may affect native fish populations (Nico, Martin, 2001).

Several approaches to evaluate genetic divergence among different populations have been carried out in order to relate these findings with contrasting life history traits (Reznick, 1982; Reznick, Bryga, 1987) and invasion success (Lindholm et al., 2005). Genetic differentiation was also interpreted as being the consequence of independent cases of incipient speciation in $P$. reticulata (Alexander, Breden, 2004; Russell, Magurran, 2006). Indeed, two new species, formerly regarded as populations of $P$. reticulata, were recently described (Poeser et al., 2005; Schories et al., 2009). Molecular phylogenetic analyses, finally revealed that these three guppy species are old species, which arose by parallel evolution rather than being emerging new species (Schories et al., 2009). Therefore, a proper taxonomic identification and molecular characterisation of introduced populations of the invasive $P$. reticulata is necessary. Similarly, color polymorphisms in males should also be reported for each locality since they play a central role in female mate choice (Godin, Dugatkin, 1996) finally leading to strong social influences on female generalized and repeatable traitcopying behaviour (Godin et al., 2005). A conspicuously colored male is also a male that presents improved behavior traits (boldness and escape distance) against fish predators (Godin, Dugatkin, 1996). Therefore, female choosing such a male would gain these indirect fitness benefits. Color patterns are also relevant to evade or confuse visually oriented predators (Endler, 1978). Ultimately, the spatial distribution of melanophores, is decisive for the differentiation between $P$. reticulata and $P$. wingei Poeser, Kempkes \& Isbrücker, 2005 (Poeser et al., 2005).

The objective of this paper is to characterize introduced specimens of $P$. reticulata collected in the lower Paraguay River drainage by means of molecular and taxonomic approaches. We further explore the genetic identity and singularity of these specimens by means of DNA Barcoding.

\section{Materials and Methods}

Study Area. The Paraguay River extends 2,670 km southwards from its source in the western hills of the Brazilian Shield to its confluence with the Paraná River, encompassing an area of more than 1 million of $\mathrm{km}^{2}$ draining areas of Brazil, Bolivia, Paraguay and Argentina. The Paraguay River is scarcely disturbed by human activities and fisheries are still at a low level of exploitation when compared with the Paraná and Uruguay rivers (Quirós et al., 2007). The meridional section of the Paraguay River between the Apa River and the confluence with the Paraná River represents the Lower Paraguay (Neiff, 1990). Introduced specimens of $P$. reticulata included in our analyses were collected in a restricted biotope ( $26^{\circ} 11^{\prime} 52^{\prime \prime}$ and $\left.58^{\circ} 13^{\prime} 1.5^{\prime \prime}\right)$ of the lower Paraguay River basin, in the province of Formosa, Argentina. Collecting site averaged a depth of $48 \mathrm{~cm}$ and its largest wetted width was $1.6 \mathrm{~m}$. Water velocity at time of sampling was almost nil. Instream macrophytes were represented by submersed and floating forms that hardly cover more than $30 \%$ in a stream reach of $50 \mathrm{~m}$. Bottom was dominated by soft sediments and fish cover was limited to macrophytes mats. This channel tributes its waters to the Pucú stream, a natural tributary of the lower Paraguay River (Fig. 1).

Fish sampling and taxonomy. Fishes were collected with hand and seine nets during a sampling program of the lower Paraguay River fish fauna. Individuals were identified with the taxonomic literature available (Rush Miller et al., 2010), measured and sexed. Meristic and basic morphometrics were obtained from specimens after fixation. Meristic counts included total fin rays, and the number of scales in predorsal, lateral, circumpeduncular and transverse series. Basic morphometrics were obtained with a digital caliper under 10X augmentation from point to point. Color pattern in males was described following Kottler et al. (2013). 

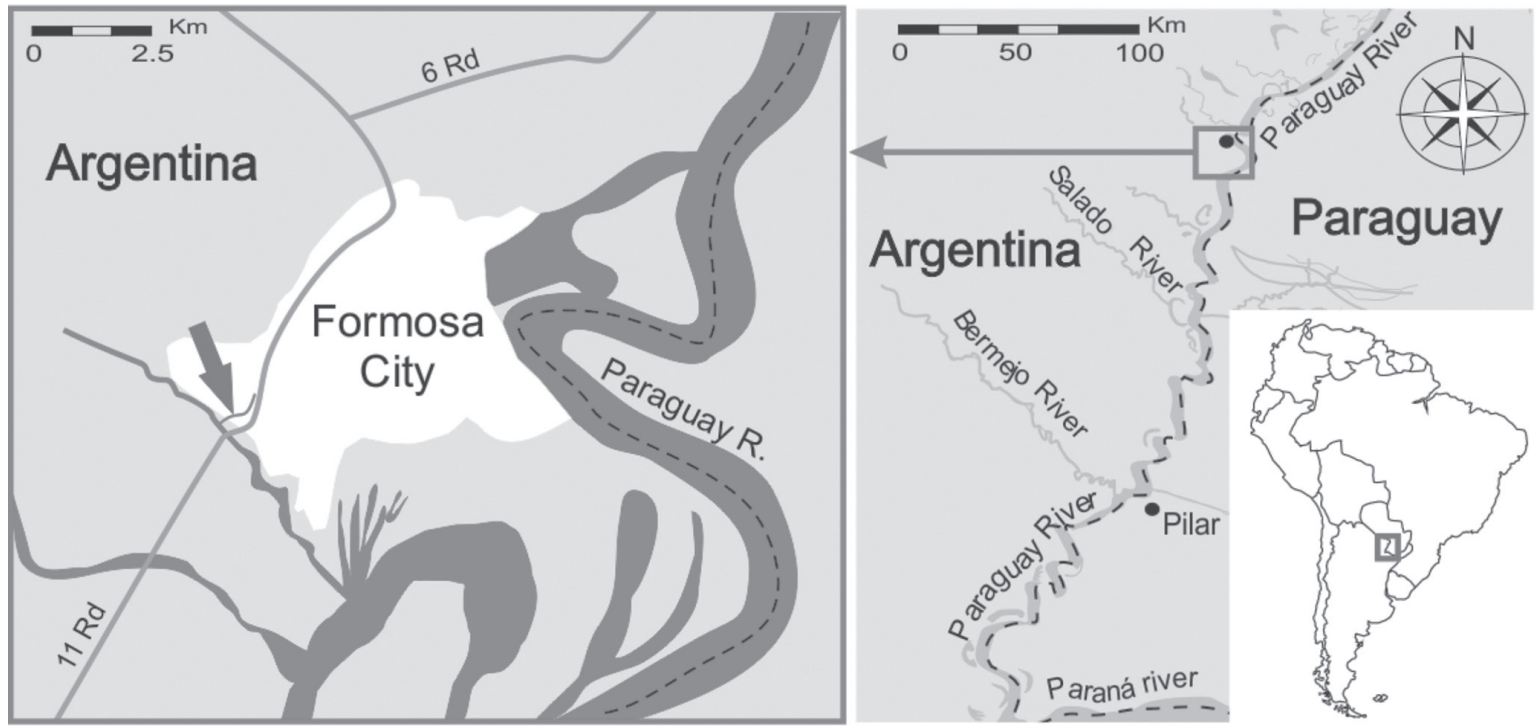

Fig. 1. Map of the study area showing the exact location of the collecting site.

Molecular analysis. A total of five individuals were subsampled in order to extract a piece of white muscle for molecular analysis. For each individual a segment of the mitocondrial DNA corresponding to the 5' region of COI was sequenced. Standard DNA barcoding protocols (Ivanova et al., 2006) were followed for DNA extraction, polymerase chain reaction (PCR) and sequencing. Extraction, PCR and sequencing protocols are described in Rosso et al. (2012). For each sequence, the Barcode Index Number (BIN) was reported. The Barcode of Life DataSystem (BOLD) was explored for additional sequences and BINs of $P$. reticulata in order to seek for an agreement at a specific level. Sequence divergences among BINs and their geographic distributions around the world were reported. Sequence divergences were calculated using the Kimura two parameter (K2P) distance model (Kimura, 1980). A neighbour-joining (NJ) tree of K2P distances was constructed to displayed genetic divergences. Poecilia vivipara Bloch \& Schneider, 1801 (the type species of the genus and the only former species of this genus reported for Argentina) and Poecilia mexicana Steindachner, 1863 were included as outgroups.

\section{Results}

A total of 13 individuals of $P$. reticulata were collected. No other accompanying fishes were present at time of sampling. Voucher specimens were deposited in the fish collection of the Instituto de Investigaciones Marinas y Costeras (UNMDPCONICET) in Mar del Plata, Argentina. Morphometrics of collected specimens are displayed in Tab. 1. Total dorsal-fin rays $7(\mathrm{n}=13)$, total pectoral-fin rays $14(\mathrm{n}=11), 15(\mathrm{n}=2)$, total pelvic-fin rays $6(\mathrm{n}=13)$, total anal-fin rays 8 (all males), 9 (all females), branched caudal-fin rays $12(\mathrm{n}=1), 13(\mathrm{n}=10), 14$ $(\mathrm{n}=1)$. Predorsal scales $12(\mathrm{n}=5), 13(\mathrm{n}=7)$, longitudinal scales $25(\mathrm{n}=4), 26(\mathrm{n}=4), 27(\mathrm{n}=5)$, transverse series $6(\mathrm{n}=4), 7(\mathrm{n}=9)$, scales around caudal peduncle $13(\mathrm{n}=1), 14(\mathrm{n}=11), 15(\mathrm{n}=1)$.
Some females were found with macroscopic signs of advanced incubation of embryos. Males, as usual, showed variability in coloration patterns whereas females displayed a plain gray-silvery background. Color traits in males displayed the characteristic black spots and orange blotches (Fig. 2).

Neither anterior or posterior black horizontal stripes nor ventral black lining of caudal peduncle or black pigment on dorsal fin were observed. None of the collected males showed the characteristic blue iridescent spot of wild males. However, the caudal-black spot was surrounded by a blue ring in some males. Caudal fin did not displayed the orange-black lining nor the black spot on ventral lobe. Conversely, caudal fin displayed different combinations of concentrated melanophores, black or orange spots and white or orange stripes.

Tab. 1. Morphometrics of collected specimens of Poecilia reticulata from lower Paraguay River basin, Formosa, Argentina. Values 1-8 are percentages of the standard length and values 9-11 are percentages of head length.

\begin{tabular}{lcc}
\hline & Males $(\mathrm{n}=7)$ & Females $(\mathrm{n}=6)$ \\
\hline Standard Length $(\mathrm{mm})$ & $14.3-16.9$ & $17.2-22.1$ \\
\hdashline 1. Head length & $26.9-29.7$ & $25.4-29.9$ \\
2. Predorsal distance & $54.4-59.7$ & $54.8-64.5$ \\
3. Dorsal-fin base length & $8.99-10.8$ & $8.1-10$ \\
4. Anal-fin base length & $6.42-8.63$ & $7.2-8.8$ \\
5. Body depth & $21.8-24.3$ & $22.6-24.3$ \\
6. Pre-pelvic distance & $40.7-44.6$ & $43.6-50.1$ \\
7. Pre-anal distance & $46.9-52.1$ & $59.3-63.3$ \\
8. Caudal peduncle depth & $17.6-19.5$ & $15.1-17.2$ \\
9. Snout length & $16.1-25.9$ & $23.7-29.5$ \\
10. Orbital diameter & $31.7-37.2$ & $30.8-34.9$ \\
11. Postorbital length & $40.7-46.8$ & $40-51.9$ \\
\hline
\end{tabular}




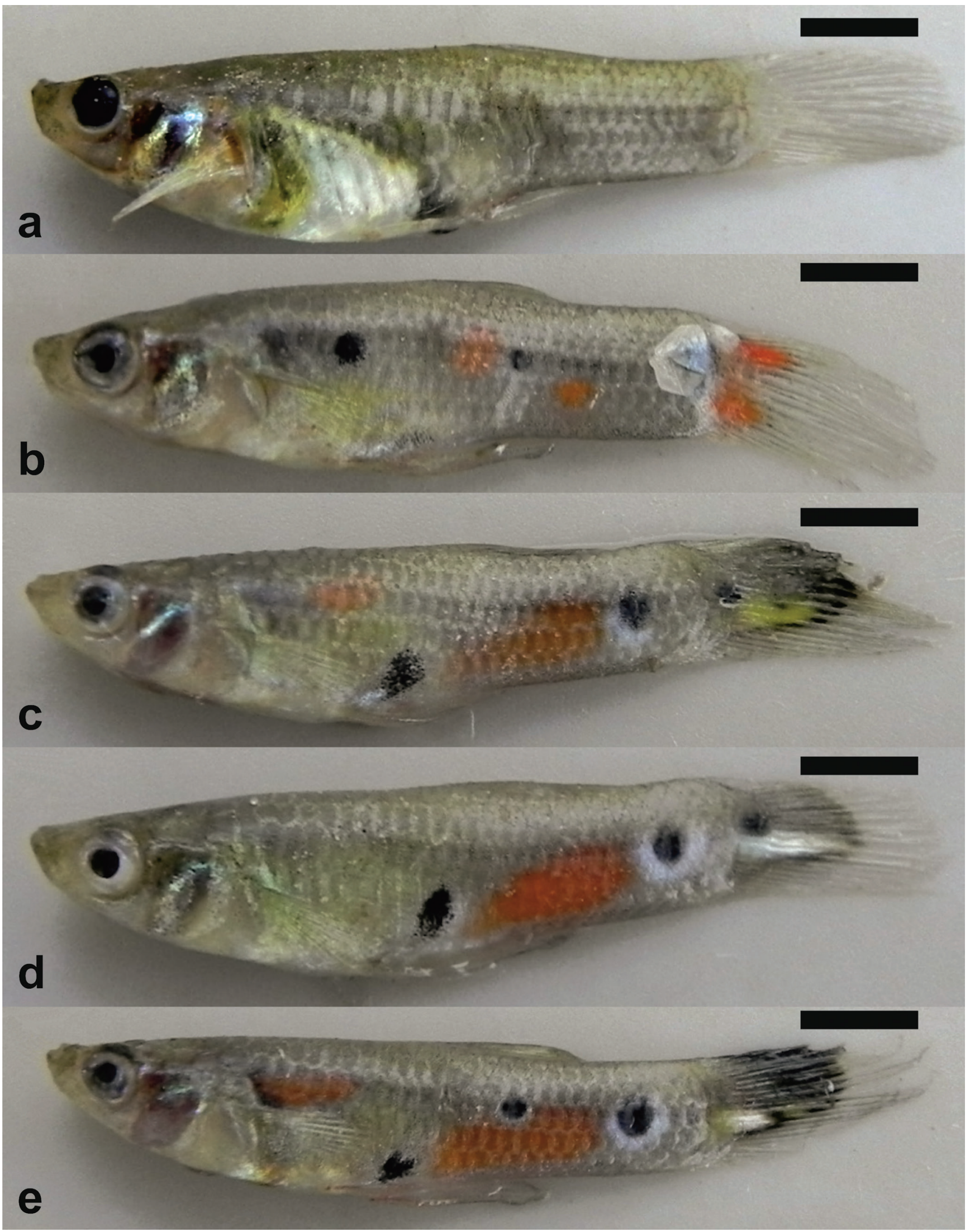

Fig. 2. Selected collected specimens of Poecilia reticulata in the lower Paraguay River. a. female: UNMDP 3687, $22.1 \mathrm{~mm}$ SL; b. male 1: UNMDP 3693, 15.9 mm SL; c. male 2: UNMDP 3694, 15.9 mm SL; d. male 3: UNMDP 3692, 16.9 mm SL; e. male 4: UNMDP 3691, $16.8 \mathrm{~mm}$ SL. Scale bars: $3 \mathrm{~mm}$. 
DNA Barcoding showed that all specimens from the lower Paraguay River belong to a single mitochondrial lineage as they were all grouped into a single BIN. This BIN, ACE3484, also contains specimens widely distributed worldwide, being detected in 11 countries of five continents (Tab. 2). Three additional BINs under the taxonomic denomination of $P$. reticulata were detected in BOLD. Mean and maximum intra-BIN genetic distances as well as distances to the nearest neighbours are also depicted in Tab. 2. The K2P NJ tree clearly grouped separately four different clusters of $P$. reticulata (Fig. 3). Nevertheless, the K2P distance was well over $2 \%$ only between BIN ACC0443 and the sister cluster composed by the three remaining BINs (Tab. 3). Among these three BINs, genetic distances ranged from 1.1 to $2.1 \%$.

Tab. 2. Geographic location and distance summary of public BIN for Poecilia reticulata. N: number of specimens; Min: minimum genetic distance whithin BIN; Max: maximum genetic distance whithin BIN; NND: nearest neighbour distance and NND BIN: Barcode Index Number of the nearest neighbour.

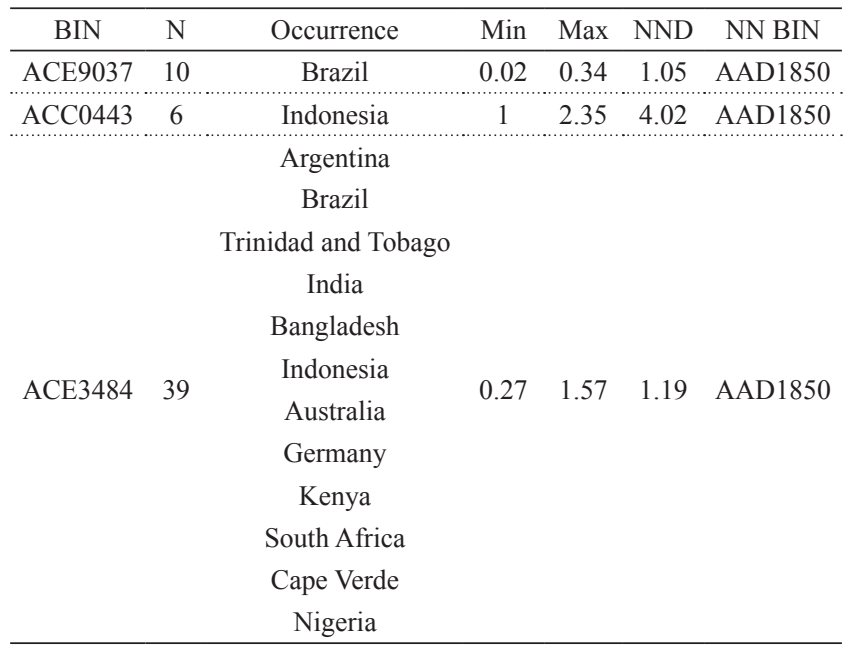

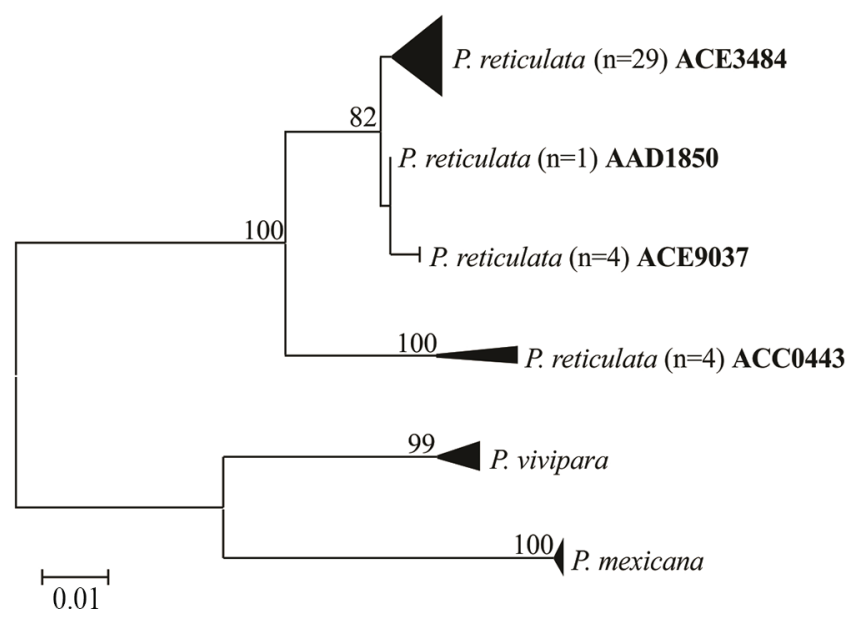

Fig. 3. NJ K2P tree of COI sequences of collected (ACE3484) specimens of Poecilia reticulata. The remaining sequences of this species together with outgroups were gathered from BOLD.

\section{Discussion}

Among the existing valid species, $P$. wingei and $P$. obscura Schories, Meyer \& Schartl, 2009 more closely resemble $P$. reticulata. The dorsal fin count clearly distinguish $P$. reticulata (7) from the recently described $P$. obscura (6). Females of $P$. wingei are indistinguishable from those of $P$. reticulata (Poeser et al., 2005). Instead, males of $P$. reticulata are larger and lack the conspicuous vertical band sometimes present in the midsection of the body, at the anterior part of the caudal peduncle of $P$. wingei.

The occurrence of $P$. reticulata in the lower Paraguay River basin represents the first record of this species for freshwater ecosystems of Argentina. This genus was recorded only once in natural environments of Argentina. The species reported was $P$. vivipara (Pozzi, 1945; Ringuelet, 1967). However, the presence of this species was never referred to collected and preserved specimens and therefore Koerber, Litz (2014) sugested not regarding this species as present in Argentina. Consequently, the record of $P$. reticulata in the lower Paraguay River basin, in Formosa province, also represents the first record of the genus in Argentina supported by preserved specimens.

The analysis of the global distribution of $P$. reticulata revealed that this species is now established in at least 69 countries outside of its native range (Deacon et al., 2011). International online databases reported that $P$. reticulata was collected only once in the Paraguay River basin. The exact location $\left(25^{\circ}\right.$ $10^{\prime} 12^{\prime \prime} \mathrm{S}, 57^{\circ} 30^{\prime} 0^{\prime \prime} \mathrm{W}$ ) is a small stream near Costa Azul town, $200 \mathrm{~m}$ from highway Asunción-Ciudad del Este (GBIF, 2016). Introduced populations in Paraguay are considered to be established (Deacon et al., 2011). However, it was not until recently, that the presence of $P$. reticulata in this country was confirmed by inspection of voucher material deposited in museums (Lucinda, 2017). Most of the localities reported by this author are concentrated in the lower Paraguay River, near the border with Argentina. Therefore, this could be one of the plausible sources for the introduced populations recorded in the lower Paraguay River in Argentina. Alternatively, unscrupulous release from aquarists may also explain this finding. Irrespective of the source, the presence of $P$. reticulata in an open waterway with known connectivity to a natural stream is of major concern.

During simultaneous field trips in other river reaches of the lower Paraguay River basin, several specimens of two native Cyprinodontiformes (Phallotorynus Henn and Cnesterodon Garman) not previously recorded for this area were also collected. Naturally, the autoecology of these small-sized species in the lower Paraguay River is unknown. Consequently, little can be anticipated about the impact of a likely invasion of $P$. reticulata on natural populations of these species. Nevertheless, the dramatic and human-mediated range expansion of the invasive $P$. reticulata can negatively impact native freshwater communities (Deacon et al., 2011). Therefore, possible interactions between $P$. reticulata and these native Cyprynodontiformes in the lower Paraguay River, could lead to a negative effect on native species if this invasive fish spreads further within this river network. 
Tab. 3. Summary of genetic distances among BINs of Poecilia reticulata and both species of Poecilia utilized as outgroups. Mean: mean within group distance.

\begin{tabular}{|c|c|c|c|c|c|c|c|c|}
\hline & & \multirow{2}{*}{$\mathrm{N}$} & \multirow{2}{*}{ Mean } & \multicolumn{5}{|c|}{ Mean between group distance } \\
\hline & & & & AAD1850 & ACC0443 & ACE3484 & ACE9037 & AAC0279 \\
\hline P. reticulata & AAD1850 & 1 & & & & & & \\
\hline P. reticulata & ACC0443 & 4 & 0.015 & 0.045 & & & & \\
\hline P. reticulata & ACE3484 & 20 & 0.004 & 0.016 & 0.051 & & & \\
\hline P. reticulata & ACE9037 & 4 & 0.000 & 0.011 & 0.051 & 0.021 & & \\
\hline P. vivipara & $\mathrm{AAC} 0279$ & 7 & 0.006 & 0.138 & 0.155 & 0.148 & 0.145 & \\
\hline P. mexicana & AAA4518 & 8 & 0.003 & 0.148 & 0.153 & 0.152 & 0.150 & 0.103 \\
\hline
\end{tabular}

Our analysis of COI sequences evidenced a marked divergence among populations of $P$. reticulata around the world. Earlier studies on allozyme and DNA sequences also revealed a marked genetic differentiation among guppy populations (Carvalho et al., 1991; Shaw et al., 1991). Whether these genetic divergences match taxonomic divergences is a matter of debate. For some authors, this genetic differentiation is the consequence of independent cases of incipient speciation (Alexander, Breden, 2004; Russell, Magurran, 2006). Conversely, Poeser et al. (2005) considered this genetic divergence as a case of genetic differentiation without speciation.

In our study, the genetic divergence between the two most disparate BINs of $P$. reticulata almost paralleled genetic distances between this species and other species of the same genus (but different subgenus) as $P$. mexicana and $P$. vivipara. Therefore, the likely occurrence of a complex of species under the taxonomic denomination of $P$. reticulata should not be completely disregarded. Several other species of the genus Poecilia were erected as species complex. Particularly, Poecilia sphenops Valenciennes, 1846 was considered to be a species complex by Alda et al. (2013) and a recent revision of the phylogeny and biogeography of poeciliids (Ho et al., 2016) also regarded P. mexicana and Poecilia latipinna (Lesueur, 1821) as species complexes.

Genetic divergences within $P$. reticulata could also be partially explained by misidentifications. Due to identical meristic counts and similar color patterns between females of $P$. reticulata and $P$. wingei (Poeser et al., 2005), the possibility of females of $P$. wingei being mislabelled as $P$. reticulata by non-taxonomist researchers for some of the published BINs should not be disregarded. Nevertheless, this will only account for one (assuming a unique BIN for $P$. wingei) of the four BINs reported for P. reticulata worldwide and therefore, the hypothesis of a species complex is still valid. The specimens of the lower Paraguay River were unambiguously identified as $P$. reticulata and not $P$. obscura and $P$. wingei following dorsal fin counts and male color patterns respectively. Therefore, we provided the DNA Barcode library with a reference BIN for $P$. reticulata further supported by Museum vouchers. This certainly will aid in future analyses of introduced populations of Poecilia regarded as being $P$. reticulata. Irrespective of the genetic identity, a phylogenetic study revealed that these three species ( $P$. reticulata, $P$. wingei and $P$. obscura) are different taxonomic units (Schories et al., 2009).
Investigations in Trinidad (Reznick, 1982; Reznick, Bryga, 1987; Reznick et al., 1990) demonstrated that guppies exposed to increasing levels of predation intensity on larger specimens mature at a smaller size, displayed a higher allocation of energy to reproduction and consequently reproduced more frequently with more and smaller offspring. The top predator in these fundational studies were fish of the genus Crenicichla (Cichlidae), a locally abundant genus in the lower Paraguay River basin. Therefore, it could be argued that $P$. reticulata already possesses the behavioural traits and life history adaptability to deal with this predator. Nevertheless, observed size range of males suggested that introduced specimens collected in the lower Paraguay River were not exposed yet to a intense risk of predation. This may be inferred, by the wider size range (suggestive of low risk of predation on larger specimens) observed in the lower Paraguay River, compared with the narrower size ranges reported for populations under high risk of predation living in natural streams (Reznick, Endler, 1982).

Due to ovoviviparity and sperm storage (Meffe, Snelson, 1989) it could be expected that the small number of "founders" collected will finally suceed into a established population. Indeed, experimental studies demonstrated that a single individual of $P$. reticulata can lead to flourishing populations of this invasive fish and called for caution when introducing this species to natural ecosystems (Carvalho et al., 1996; Deacon et al., 2011). Albeit equiped with these adaptive reproductive traits, founders must also face regulatory factors derived from interactions with other fishes, either competitors or predators.

The molecular and taxonomic characterisation of the introduced specimens of $P$. reticulata collected in the lower Paraguay River basin, certainly will aid in scrutinizing the identity of eventual future records of this exotic invasive species in the lower Plata River basin. So far, the detection of the first individuals may lead to timely management actions impairing the successful establishment of this invasive species. Of central importance it is also to further trace the original source of this introduced population as well as to explore its connectivity with nearby populations. For conservation purposes, the geographic occurrence and abundance distribution of this species within the lower Paraguay River should be mapped. 


\section{Acknowledgments}

This research was partially funded by "Bosques Nativos Argentinos para la Biodiversidad" and Ministerio de Producción y Ambiente of Formosa. JJR acknowledges the financial support from the International Development Research Centre (IDRC) of Canada. JJR, EM, EA and JMDA acknowledge the support provided by the Consejo Nacional de Investigaciones Científicas y Técnicas (CONICET) of Argentina.

\section{References}

Alda F, Reina RG, Doadrio I, Bermingham E. Phylogeny and biogeography of the Poecilia sphenops species complex (Actinopterygii, Poeciliidae) in Central America. Mol Phylogenet Evol. 2013; 66(3):1011-26.

Alexander HJ, Breden F. Sexual isolation and extreme morphological divergence in the Cumaná guppy: a possible case of incipient speciation. J Evol Biol. 2004; 17(6):1238-54.

Allen GR, Midgley SH, Allen M. Field guide to the freshwater fishes of Australia. Perth: Western Australian Museum; 2002.

Carvalho GR, Shaw PW, Hauser L, Seghers BH, Magurran AE. Artificial introductions, evolutionary change and population differentiation in Trinidadian guppies (Poecilia reticulata: Poeciliidae). Biol J Linn Soc. 1996; 57(3):219-34.

Carvalho GR, Shaw PW, Magurran AE, Seghers BH. Marked genetic divergence revealed by allozymes among populations of the guppy Poecilia reticulata (Poeciliidae), in Trinidad. Biol J Linn Soc. 1991; 42(3):389-405.

Courtenay WR Jr, Stauffer JR Jr. The Iintroduced fish problem and the Aquarium fish industry. J World Aquacult Soc. 1990; 21(3):145-59.

Deacon AE, Ramnarine IW, Magurran AE. How reproductive ecology contributes to the spread of a globally invasive fish. PLoS ONE. 2011; 6(9):e24416.

Dill WA, Cordone AJ. History and status of introduced fishes in California, 1871-1996. California Department of Fish and Game; 1997. (Fish Bulletin; 178).

Endler JA. A predator's view of animal color patterns. In: Hecht MK, Steere WC, Wallace B, editors. Evolutionary Biology. Boston: Springer; 1978. p.319-364. (Evolutionary Biology; v. 11).

Global Biodiversity Information Facility (GBIF). GBIF Occurrence Download. 2016 [cited 2016 Nov 4). Available from: http://doi. org/10.15468/dl.n0zl2a

Godin J-GJ, Dugatkin LA. Female mating preferences for bold males in the guppy, Poecilia reticulata. Proc Natl Acad Sci USA. 1996; 93(19):10262-67.

Godin J-GJ, Herdman EJE, Dugatkin LA. Social influences on female mate choice in the guppy, Poecilia reticulata: generalized and repeatable trait-copying behaviour. Anim Behav. 2005; 69(4):999-1005.

Ho AFLC, Pruet CL, Lin J. Phylogeny and biogeography of Poecilia (Cyprinodontiformes: Poeciliinae) across Central and South America based on mitochondrial and nuclear DNA markers. Mol Phylogenet Evol. 2016; 101:32-45.
Ivanova NV, Dewaard JR, Hebert PDN. An inexpensive, automation-friendly protocol for recovering high-quality DNA. Mol Ecol Notes. 2006; 6(4):998-1002.

Kimura M. A simple method for estimating evolutionary rate of base substitutions through comparative studies of nucleotide sequences. J Mol Evol. 1980; 16(2):111-20.

Koerber S, Litz TO. On the erroneous records of Poecilia vivipara from Argentina. Ichthyological Contributions of Peces Criollos. 2014; 33:1-4.

Kottler VA, Fadeev A, Weigel D, Dreyer C. Pigment Pattern Formation in the Guppy, Poecilia reticulata, involves the Kita and Csf1ra Receptor Tyrosine Kinases. Genetics. 2013; 194(4):631-46.

Lindholm AK, Breden F, Alexander HJ, Chan WK, Thakurta SG, Brooks R. Invasion success and genetic diversity of introduced populations of guppies Poecilia reticulata in Australia. Mol Ecol 2005; 14(12):3671-82.

Lucinda PHF. First confirmed records of the guppy, Poecilia reticulata, from Paraguay. Ichthyological Contributions of Peces Criollos. 2017; 51:1-4.

Magurran AE. Evolutionary ecology: the Trinidadian guppy. Oxford: Oxford University Press; 2005.

Meffe GK, Snelson FF Jr. An ecological overview of poeciliid fishes. In: Meffe GK, Snelson FF Jr, editors. Ecology and Evolution of Livebearing Fishes (Poeciliidae). New Jersey: Prentice Hall, Englewood Cliffs; 1989. p.13-31.

Neiff JJ. Ideas para la interpretación ecológica del Paraná. Interciencia. 1990; 15(6):424-41.

Nico LG, Martin RT. The South American suckermouth armored catfish, Pterygoplichthys anisitsi (Pisces: Loricariidae), in Texas, with comments on foreign fish introductions in the American southwest. Southwest Nat. 2001; 46(1):98-104.

Poeser FN, Kempkes M, Isbrücker IJH. Description of Poecilia (Acanthophacelus) wingei n. sp. from the Paría Peninsula, Venezuela, including notes on Acanthophacelus Eigenmann, 1907 and other subgenera of Poecilia Bloch and Schneider, 1801 (Teleostei, Cyprinodontiformes, Poeciliidae). Contrib Zool. 2005; 74(1/2):97-115.

Pozzi AJ. Sistemática y distribución de los peces de agua dulce de la República Argentina. GAEA. 1945; 7(2):239-92.

Quirós R, Bechara JA, de Resende EK. Fish diversity and ecology, habitats and fisheries for the un-dammed riverine axis Paraguay-Parana-Rio de la Plata (Southern South America). Aquat Ecosyst Health Manage. 2007; 10(2):187-200.

Reznick D. The impact of predation on life-history evolution in Trinidadian guppies: genetic basis of life-history patterns. Evolution. 1982; 36(6):1236-50.

Reznick DN, Bryga H. Life-history evolution in guppies (Poecilia reticulata): 1. Phenotypic and genetic changes in an introduction experiment. Evolution. 1987; 41(6):1370-85.

Reznick DN, Bryga H, Endler JA. Experimentally induced life history evolution in a natural population. Nature. 1990; 346(6282):357-59.

Reznick D, Endler JA. The impact of predation on life history evolution in Trinidadian guppies (Poecilia reticulata). Evolution. 1982; 36:160-77. 
Ringuelet RA, Arámburu RH, Alonso de Arámburu A. Los peces argentinos de agua dulce. La Plata: Comisión de Investigaciones Científicas de la Provincia de Buenos Aires; 1967.

Rosen DE, Bailey RM. The Poeciliid Fishes (Cyprinodontiformes), their structure, zoogeography and systematics. Bull Am Mus Nat Hist. 1963; 126:1-176.

Rosso JJ, Mabragaña E, Gonzalez Castro M, Diaz de Astarloa JM. DNA barcoding Neotropical fishes: recent advances from the Pampa Plain, Argentina. Mol Ecol Resour. 2012; 12(6): 999-1011.

Rush Miller R, Minckley WL, Norris SM. Peces dulceacuícolas de México. México: Comisión Nacional para el Conocimiento y Uso de la Biodiversidad; 2010.

Russell ST, Magurran AE. Intrinsic reproductive isolation between Trinidadian populations of the guppy, Poecilia reticulata. J Evol Biol. 2006; 19(4):1294-303.
Schories S, Meyer MK, Schartl M. Description of Poecilia (Acanthophacelus) obscura n. sp., (Teleostei: Poeciliidae), a new guppy species from western Trinidad, with remarks on $P$. wingei and the status of the "Endler's guppy". Zootaxa. 2009; 2266:35-50.

Shapovalov L, Cordone AJ, Dill WA. A list of the freshwater and anadromous fishes of California. Calif Fish Game. 1981; 67:4-38

Shaw PW, Carvalho GR, Magurran AE, Seghers BH. Population differentiation in Trinidadian guppies (Poecilia reticulata): patterns and problems. J Fish Biol. 1991; 39(SA):203-09.

Vipan JAM. Malaria and the 'millions' fish (Girardinus poeciloides). Proc Zool Soc Lond. 1910; 146-47.

Submitted January 10, 2017

Accepted October 23, 2017 by Paulo Lucinda 